Pobrane z czasopisma New Horizons in English Studies http://newhorizons.umcs.pl Data: 26/04/2023 13:22:38

New Horizons in English Studies 5/2020

REVIEW

Q

Monika Kosa

BabeȘ-Bolyai University, Romania

KOSAMONIKA@YAHOO.COM

HTTPS://ORCID.ORG/OOOO-0OO2-1039-9989

\title{
Challenging Anthropological Thinking at the Intersection of Posthumanist Dream Writing and Animal Studies
}

\section{Susan Mary Pyke. Animal Visions: Posthumanist Dream Writing. Cham: Springer International Publishing. 2019, 314 pp.}

Considering the growing scholarly interest in animal studies and its vast interdisciplinary applicability, Susan Mary Pyke's Posthumanist Dream Writing is an influential and complex study of the literary responses to the detrimental potentialities of anthropocentrism with a special emphasis on Emily Bronte's canonic novel, Wuthering Heights, and its several literary and some cinematic adaptations which problematize speciesism. Thus, by drawing on the theories of Cixous, Derrida, and Freud among others, the book is a great contribution to (and simultaneously a reflection on) animal literary scholarship and argues that (non-anthropocentric) dream writing is an important tool which has the potential to dismantle unsettling human privileging that has dominated the theoretical horizons of Western thinking over the centuries.

Constructed at the intersections of literature, anthropology, cultural studies, ecofeminism, ethics, history, and animal studies, Posthumanist Dream Writing explores and deconstructs the culturally embedded ideas regarding human superiority over nonhuman subjects. Divided into six comprehensive chapters, the book incorporates the concept of posthumanist dream writing as a crucial tool to dismantle the hierarchical oppression 
of nonhuman animals and to shed light on the several injustices against animals, both in cultural practices and linguistic structures. The first chapter is introductory and is mostly concerned with theoretical delimitations, whereas the second focuses on the subversive potentialities of the textual responses to Wuthering Heights, arguing that dream writing is a subversive act which can challenge deeply-rooted anthropocentric ideas. The third chapter deals with (inter)textual ghosts and hauntings, the fourth explores spatiality and introduces the phrase 'moor love' to refer to literary topographies which dismantle the boundaries between humans and animals, the fifth dives deeper into the semantic potentialities of 'moor love' and its transgressive potential and the last chapter reinforces the idea that posthumanist dream writing is a useful tool to dismantle anthropo-theological domination.

Emily Bronte's highly metaphorical and complex Wuthering Heights serves as the main literary text which "offers an alternative to anthropo-theological thinking" (10). Furthermore, the several textual responses Bronte's magnum opus generated reinforces the novel's relevance within the cultural canon. As Susan Mary Pyke traces back posthumanist dream writing to the Romantic era, the Romantic Gothic and its subsequent tropes of entrapment is revealed to be a key-feature of the masterpieces written by the Bronte sisters. In the next part, Pyke parallels masculinist carceration with animal exploitation, making an interesting analogy between the two forms of abuse. Drawing on contemporary ecocritical studies, philosophy, and psychology, the author analyzes Wuthering Heights as post-anthropocentric text which "resists antropo-theological dominion" (24). In order to offer a more comprehensive view on how the Romantics responded to anthropocentrism, the author compares the Brontean Weltanschauung to Wordsworth's works, which allows the readers to understand Emily Bronte's non-anthropocentric position while also offering an insightful view into the historical progression from Romanticism to Emily Bronte's post-romantic oeuvre.

The dreamscapes from Wuthering Heights are central to the exploration of Bronte's text and to the post-anthropocentric views the novel conveys. After explaining Freud's immense contribution to dream studies, for whom dreams are reflective of the dreamer's psyche, anxieties and desires, the author opts to filter the Brontean masterpiece through the lens of Cixous, who envisages dreamscapes as subversive topographies. The mesmerizing dream-writing, as Pyke insists, is a framework which allows to subvert human mastery and generates new ways of comprehending the environment and its co-inhabitants or earth-others. Furthermore, dream writings resist normative categorization and disrupts exclusively humanistic worldviews, which appear embedded in the Western cultural consciousness, offering an alternative that is not limited by exclusivist rational ontologies. Post-Freudian dream readings are always shifting, in-process responses to texts as regenerative processes which allow for enriching one's way of experiencing the world and these readings are cross-infected by other beings, including other species as well.

One of the most interesting subchapters, "Hystericised Hauntings", deals with textual ghosts and explores hysteria, with its subsequent gendered tropes (madwoman and witch), as a form of "cultural control" (45), an idea the author connects with female oppression and even the oppression of other species. Like hysteria, closeness to other 
species and affectionate interspecies relations were associated with malady, presumably by the patriarchist imagination, Pyke explains. Freud's extensive, yet limited study on hysteria, is challenged by Cixous' textual response to Freud's case study. Cixous' text emphasizes the complexity of the condition and its oppressive function within cultural spaces. The author analyzes the peri-hysterical 'acting outs' from Wuthering Heights-most notably Cathy's 'hauntings' in order to explore forms of resistance--such as silence--against restrictive norms and the refusal to inhabit a patriarchal, human-centered society. The accommodation of peri-hysteria in dream writings has the potential to open up new ways of improving cross-species relations and to resist oppression, be it human or patriarchal. The conclusion of the chapter is that dream writing and its co-affective allure has the potential to stimulate the reader to respond in imaginative and unexpected ways, disrupting rational impositions or normative boundaries.

The literary adaptations of Wuthering Heights mentioned in the book include Anne Bronte's The Tenant of Wildfell Hall, Olive Schreiner's The Story of an African Farm, George Brown's The House with Green Shutters, Maryse Conde's Windward Heights or Alice Hoffman's Here on Earth. These intertextual references are mentioned in order to highlight the original text's semantic potentiality and the myriad of perspectives and meanings that the novel generates, inspiring other writers to create textual responses, establishing a complex web of literary ramifications, transhistorical and transcultural. Pyke opts to focus extensively on selected adaptations in which the applicability of dream writing to foster inclusive cross-species relations is explored. Consequently, dream reading is applied to two intertextual ghost-poems, Kathy Acker's Obsession and Anne Carson's The Glass Essay. Similarly to the speaker from Carson's visionary poem, inspired by Bronte's Cathy and her mesmerizing dreams, Carson's readers are expected to respond to rich layers of meaning from these dreams and to engage in interpretative processes which foster non-anthropocentric views.

In all of these narratives, dreams play a crucial role and can open up new interpretative ways, as the author insists in various instances. Pyke offers an interesting reading of the dreams from the original novel, emphasizing how dream reading can reveal the anthropocentric aspects of Lockwood's personality, for instance. On the other hand, Acker's disturbing and tragic poem projects polyphonous dreamscapes inspired from the Brontean text that problematize dreams as freeing agency which allows Kathy (Cathy) to "override the niceties of social convention" (132). After analyzing Carson's meditative poem and its enchanting dreamscapes, Pyke concludes that these textual responses entail an openness towards cross-species relations, fostering co-affective relations and refusing to enclose (posthuman) existence into a well-patterned box of selfish anthropocentrism. In other words, by expanding post-Freudian notions of dream analysis, the author traces posthumanist dream writing in the dreamscapes of Bronte, Acker and Carson in order to reinforce the potential of dream writing as liberating agency from the constraints of anthropocentrism.

An interesting part of the book deals with the emplaced spectral presence of the moor and Emily Bronte's ghost, tropes later adapted in Carson's Obsession, Urquhart's 
Changing Heaven and Davies' Four Dreamers and Emily. The moor, the key-topography of the novel, is "a space where patterns are made outside utilitarian human preferences and expectations" (196). The moor displaces "assumptions that the (cis white male) human is at the apex of control in the world, thus making space for more equitable ways of being with animal others" (196) by existing outside the man-made rules of human societies. The moor has several functions in these dream-narratives. For instance, in Carson's poem, Emily's ghost and the moor have a liberating and empowering function, offering the speaker an opportunity to escape the restraining social codes and family expectations. The ghostly Emily from the metanarrative Changing Heaven, on the other hand, is a postmodern figuration which engenders disruptive perspectives on humanist and patriarchal positions and empowers the female protagonist, Ann, to escape the male gaze in a highly symbolic and self-referential text.

Pyke integrates a collage of metaphors, such as literary as well as cinematic topographies--most notably, the highly metaphorical moor-image--to expose the co-affective potentialities of the original text which aims to promote a posthumanist worldview. Furthermore, Pyke discusses how Heathcliff is as much a beast as he is human, disrupting the distinctive line that separate mankind from the animal world and engages in an intertextual analysis by comparing Bronte's take on the demonic Heathcliff with Acker's version of this complex character. The study entails strong interdisciplinary references and the subchapter "The Gaze of the Cinamatic 'I" explores the cinematic responses to the Brontean text and their visual potential to nurture cross-species relations. Such cinematic responses include Bunuel's Abismos de Pasion, a surrealist cinematic masterpiece, and Arnold's Wuthering Heights, a romantic drama movie, both of which explore, in a visually stunning manner, cross-species relations and engage in directly exposing to the audience the often selfish and cruel acts of humans towards the animal others and offer a filmic space for animals to expose their complex personhood.

Filtered through the cultural lens of ecofeminism, Pyke's interdisciplinary study insists on the necessity of defining existence as a dynamic, diverse, and inclusive process in a shared and entangled universe. The conclusion of the study is that "posthumanist dream writing moves beyond human centrality, refusing anthropocentric idealisations of human individuation" (142). Dreams are analyzed as an ever-shifting mode of reconfiguring the world, as complex and fluid states, allowing to free the self from the constraints of anthropocentric thinking. The co-affective responses to Bronte's iconic novel included in the study reinforce position of the narrative as non-anthropocentric and nurtures post-anthropocentric thinking, which has an inclusive and positive impact on cross-species relationships. Including a vast body of critical work, ranging from Descartes to Cixous, and incorporating extensive analytical chapters on Bronte's archetypal masterpiece, Wuthering Heights, and some of its literary and cinematic adaptations, the book is a complex addition to the ever-expanding field of animal studies, offering a compelling reading on posthumanist dreamscapes as tools to generate and foster non-anthropocentric thinking and simultaneously exposing problematic aspects of human privileging, so deeply embedded in our cultural consciousness. 